Egyptian Journal of Aquatic Biology \& Fisheries

Zoology Department, Faculty of Science,

Ain Shams University, Cairo, Egypt.

ISSN $1110-6131$

Vol. 24(7): $219-231$ (2020)

www.ejabf.journals.ekb.eg

\title{
Antibacterial and Antifungal Activity with Minimum Inhibitory Concentration (MIC) Production from Pocillopora verrucosa collected from Al-Hamraween, Red Sea, Egypt
}

\author{
Moaz M. Hamed* and Hussein. N.M. Hussein \\ National Institute of Oceanography and Fisheries, Egypt \\ "Corresponding Author: Moaz-micro@hotmail.com
}

\section{ARTICLE INFO}

Article History:

Received: Sept. 20, 2020

Accepted: Oct. 18, 2020

Online: Oct. 24, 2020

Keywords:

Antibacterial,

Antifungal,

Bioactive compounds,

GC-MS analysis,

Hard corals,

Red Sea.

\section{ABSTRACT}

The trouble of antimicrobial drug resistance has presupposed a search for new antimicrobial substances from other exporters including natural sources. Marine micro-organisms are known to produce metabolites to safeguard themselves against pathogens and therefore can be deemed as a potential source of antimicrobial substances. This research intended to evaluate the antimicrobial activity of six hard coral species namely Acropora hemprichii, Acropora austera Seriatopora hystrix, Seriatopora pistillata, Pocillopora verrucosa and Millepora dichotoma against some pathogenic microbes, and the bioactive compounds were extracted using ethyl acetate. The antimicrobial activity of the extracts was estimated using the disc diffusion method. The organic extract from Pocillopora verrucosa was the most effective against all selected microorganisms except Bacillus subtillus ATCC6633 and Aspergillus flavus while the highest effect was showed against Fusarium solani $(22 \mathrm{~mm})$. Moreover, a partial description of these agents was carried out using the gasliquid chromatography (GC-Mass). The main ingredient of Pocillopora verrucosa crude extract organic acids, aldehydes, esters, carotene, and their derivatives. That is the first research about the extraction of natural bioactive compounds from Pocillopora verrucosa which located in Al-Hamraween, Red Sea, Egypt.

\section{INTRODUCTION}

The Red Sea has long been known as a region of high biodiversity (Stehli and Wells 1971; Berumen et al. 2013) Physiologically, marine organisms have the ability to develop unparalleled metabolites, to stay live in hard marine environments. These metabolites including a lot of novel secondary products with useful chemical and biological properties which couldn't be produced by terrestrial organisms (Blunt et al. 2009). For more than 30 years, marine natural products have attracted the attentiveness of scientists to isolate new biologically active components. Actually, of the 36 phyla of life, 34 are founded in the marine environment. The ocean represents a bushy exchequer for the discovery of potential therapeutic agents. However, despite the onerousness of 
survival, marine organisms have developed mechanisms to synthesize bioactive compounds to overcome these snags (Debitus 1998). In general, the prospect of natural bioactive compounds contents of almost all forms of life in the marine environment has been screened. In the marine life, sponges (37\%), coelenterates (21\%), and microorganisms (18\%) are the large exporter of bioactive compounds followed by algae, echinoderms, tunicates, molluscs, and bryozoans (Kim 2012).Although sponges are considered the major contributing marine organisms of novel bioactive compounds, little are known on the antimicrobial activity of stony corals (Qaralleh et al. 2014). Corals are qualified for prohibit unwanted bacteria by various means, like the self-cleaning of mucus from their surface. Furthermore, microbes in the surface mucus layer change the immune system by stimulating specific responses and the immune system in return influences the microbial composition (Rivera-Ortega and Thomé 2018). on antimicrobial and antifungal activity of extracts of marine organisms and the subsequent purified antibiotics isolated from these organisms were tested against human pathogens as potential novel clinically useful drugs (Kelman et al. 2006; Afifi et al. 2016; AH Ibrahim et al. 2020; Sabdaningsih et al. 2017). The effectiveness was tested and found fundamentally in marine sponges and gorgonian octocorals. a few is known on the antimicrobial activity of other corals, especially reef-building (hermatypic) stony (scleractinian) corals. This is rather astonishing, considering that these latter organisms are the most predominant and distinguished members of many reefs. The Red Sea is a resource-rich area with a distinctive ecosystem of coral reefs where soft corals are the most abundant species (Ismail et al. 2017).

The aim of the current study is to compare the antibacterial and antifungal activity of extracts of six stony coral species from the coral reef of red sea Egypt.

\section{MATERIALS AND METHODS}

\section{Study area}

Al-Hamraween is located about $60 \mathrm{~km}$ southern of Safaga, $20 \mathrm{~km}$ northern of Qusier City and about $120 \mathrm{~km}$ from the Capital City of the Red Sea governorate (Hurghada) Fig.1. The harbor occupies the southern part of the settlement lying directly on small embayment. The tidal flat off Al-Hamraween area is very narrow and extends smoothly with a very gentle slope towards the sea. The environmental system of the marine area includes dense seagrass beds, algal blooms and mostly bleached coral communities in the lee side of the tidal flat (Dar 2005; Madkour et al. 2006).

\section{Sampling and identification}

All species of hard corals were collected using SCUBA and snorkeling equipment, using under water digital camera in Al-Hamraween area. The assemble coral reefs were assembled were hard branching reefs from the parallel to the reef edge within the water at $1 \mathrm{~m}, 1.5 \mathrm{~m}, 2 \mathrm{~m}, 3 \mathrm{~m}$ to $5 \mathrm{~m}$ in depth. Each sample was cut into small pieces 
and then promptly frozen and maintained at $-20^{\circ} \mathrm{C}$ before extraction (Mohamadizadeh et al. 2014). Identification of hard coral species that were collected from the study area was carried out using available references (Veron 2000).

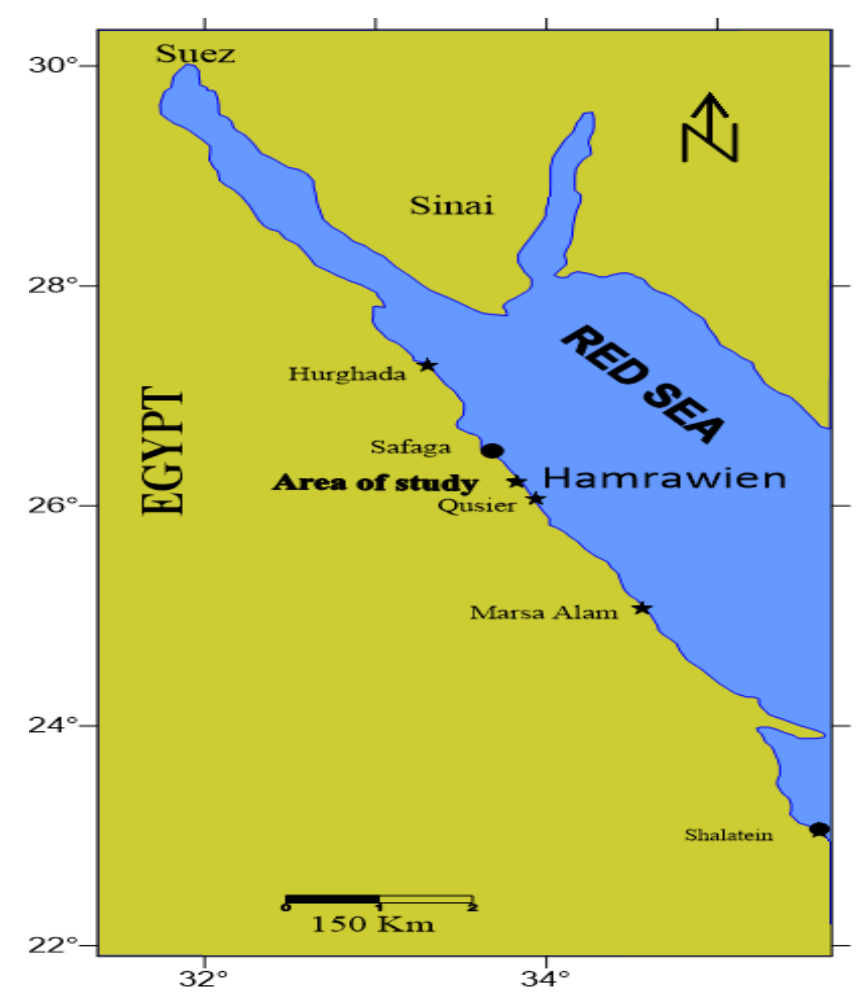

Fig.1. Map of the Al-Hamraween area and the location of sampling site

\section{Hard coral crude extracts}

The frozen samples were freeze-dried, prostrate with dry ice by a blender and drenched overnight in sterilized distilled water. The supernatants were then removed, centrifuged at 10,000 rpm, filtered and collected. The collected water extracts were freeze-dried (aqueous extract). The insoluble solid materials were then successively extracted with ethyl acetate successively by percolation (72 hours) at room temperature. The organic extracts were combined and the solvent removed by rotary evaporation at $40^{\circ} \mathrm{C}$ to eschew the compounds degradation. The crude extract was kept at $-20^{\circ} \mathrm{C}$ until further processing (Qaralleh et al. 2014).

\section{Test microorganisms}

The bacterial strains were Escherichia coli ATCC 19404, Staphylococcus aureus ATCC6538, Enterococcus faecalis ATCC29212, Bacillus subtillus ATCC6633 and Pseudomonas aeruginosa 9027 while fungal strains were Aspergillus flavus, Aspergillus terreus and Fusarium solani. All strains were obtained from microbiological lab (National Institute of Oceanography and Fishers, Egypt). The Pathogenic bacterial strains in the current study were maintained on nutrient agar slants and stored at $2{ }^{\circ} \mathrm{C}$. For long preservation, the slants were folded with $25 \%$ glycerol.

\section{Antibacterial activity}


The biological culture was performed using an agar well diffusion method. Antimicrobial activities of hard corals extract using organic solvent were performed against pathogenic selected bacteria. The antibacterial activity was done by Kir bye Bauer disk diffusion method. The pure cultures of pathogens were sub cultured in nutrient broth at $35^{\circ} \mathrm{C}$ on a rotary shaker at $120 \mathrm{rpm}$. For bacterial growth, $100 \mathrm{ml}$ fresh culture having $10^{6}$ colony forming units $(\mathrm{CFU}) / \mathrm{ml}$ of each test pathogen were grown on nutrient agar plates using a sterile L-rod spreader. After solidification, $8 \mathrm{~mm}$ wells were punched into the nutrient agar plates for testing extract. Using a micropipette, $100 \mu \mathrm{l}$ of the test sample was poured onto each well on all plates with a concentration of $100 \mathrm{mg} / \mathrm{ml}$. After overnight incubation at $35^{\circ} \mathrm{C}$, the radius of each inhibition zone was linearly measured in mm (Suresh et al. 2016).

\section{Antifungal activity}

The fungal isolates were growing in YEPD media (peptone 20g; Yeast extract; Dextrose $20 \mathrm{~g}$ and distilled water $1000 \mathrm{ml}$ ) at $25{ }^{\circ} \mathrm{C}$ for 7 days then, spores were harvested from slants, to prepare inoculums containing $10^{5}$ spores/cells $\mathrm{ml}^{-1}$ of fungi. For solidification media were add $1.5 \%$ (w/v) agar was added to the broth medium. Into sterilized plates $100 \mu \mathrm{l}$ of the indicator strain suspension was poured and overlaid with a soft agar medium cooled to $45^{\circ} \mathrm{C}$ and mixed. A culture supernatant $(100 \mu \mathrm{l})$ was added into each well with a concentration of $100 \mathrm{mg} / \mathrm{ml}$. After incubation, the antifungal activities were determined by measuring diameter of each inhibition zones (mm) (Cizeikiene et al. 2013).

\section{Minimum inhibitory concentration (MIC)}

Different concentrations of the tested coral sample from Pocillopora verrucosa (100, $75,50,25,12.5,6.25$ and $3.12 \mathrm{mg} / \mathrm{ml}$ ) were introduced on wells onto agar plates inoculated with the various pathogenic cultures. Minimum inhibitory concentration (MIC) values were taken as the lowest concentration of extract that inhibited the growth of the pathogen after $24 \mathrm{~h}$ of incubation at 37C. Microbial growth was determined by measuring the diameter of the inhibition zone area (Velmurugan et al. 2012).

\section{Statistical analysis}

Data was presented as the mean of three replicates \pm standard error (SE). XLSTAT program (version 5.03) was used for statistical analyses (Pagès et al. 2014).

\section{Characterization of crude extract}

The produced extracts from Pocillopora verrucosa were willing for GC-Mass analysis. Analysis of GC / MS was performed using a GC instrument (Agilent 7890A) equipped with an HP-5MS column $(30 \mathrm{~m} / 250 \mu \mathrm{m} / 0.25 \mu \mathrm{m}$ film thickness $)$ and a MS detector (Agilent 5975C). The initial temperature of the oven was set for holding at $90{ }^{\circ} \mathrm{C}$ for $1 \mathrm{~min}$, then rising at $8^{\circ} \mathrm{C} / \mathrm{min}$ to $300^{\circ} \mathrm{C}$ for $30 \mathrm{~min}$. Helium was used at a flow rate of $1.5 \mathrm{ml} / \mathrm{min}$ as a carrier gas. The injection volume of the sample was $1 \mu \mathrm{l}$ in the splitless mode where the injector temperature was $290^{\circ} \mathrm{C}$. Mass spectrum was operated at $70 \mathrm{ev}$ and mass range from 60-600 amu. Extracts prepared using ethyl acetate solvent and 
concentrated until complete dryness and finally resuspended in convenient volume of ethyl acetate (Ibrahim et al. 2012).

\section{RESULTS}

\section{Identification of coral species}

The collected hard corals from Al-Hamraween area as well as encountered hard corals were identified according to (Veron 2000). A total of 6 species belonging to 3 families and 4 genera were recorded in (Table.1 and Fig.2).

Table1: Red Sea hard corals identification at the study area

\begin{tabular}{c|c} 
PHYLUM & CNIDARIA \\
\hline FAMILY & Acroporidae \\
GENUS & Acropora \\
SPECIES & A. hemprichii \\
& A. austera \\
FAMILY & Pocilloporidae \\
GENUS & Seriatopora \\
SPECIES & S. hystrix \\
& S. pistillata \\
GENUS & Pocillopora \\
SPECIES & P. verrucosa \\
CLASS & Hydrozoa \\
FAMILY & Milleporidae \\
GENUS & Millepora \\
SPECIES & M. dichotoma \\
\hline
\end{tabular}

\section{Antibacterial and antifungal activity of corals}

In this study, crude extracts of six identified hard corals collected from Red Sea, Egypt were screened for their antibacterial and antifungal activity against selected bacterial and fungal indicators (Escherichia coli ATCC 19404, Staphylococcus aureus ATCC6538, Enterococcus faecalis ATCC29212, Bacillus subtillus ATCC6633, Pseudomonas aeruginosa 9027, Aspergillus flavus, Aspergillus terreus and Fusarium solani). Using ethyl acetate solvent which were selected according to different polarities. Extracts were prepared and then screened against the aforementioned bacterial andfungal pathogens using well cut diffusion method. In general, the crude extracts showed positive records against most of selected pathogens. The crude extraction from aqueous extracts tested against the pathogen and showed in (Table 2 Figure 3). The zone of inhibition (mm) ranged from (22 to 10) by Pocillopora verrucosa, Acropora austere, Seriatopora pistillata Acropora hemprichii, Millioporadichomata and Seriatopora hystrix. The highest value $(22.0 \mathrm{~mm})$ was recorded against fungal pathogens $F$. solani by the crude 
extract produced from P.verrucosa. while lowest activity $(10 \mathrm{~mm})$ showed against $F$. solani by the crude extract produced from Seriatopora pistillata. The antimicrobial study revealed that: The extract of Pocillopora verrucosa has marked effect against most tested bacterial strains either gram positive or gram-negative bacteria as well as most tested fungus strains. The MIC values of Pocillopora verrucosa curd extract against pathogenic bacteria were determined and tabulated (Table 3). Statistical analysis showed that, data do not pass the normality test, even after various treatment processes (e.g. log $(\mathrm{x}+1)$ transformation). So, a non-parametric Friedman test of differences among coral species was conducted and rendered Chi-square $\left(\chi^{2}\right)$ values of 11.08 which were significant $(\mathrm{p}<0.05)$ for ethyl acetate extractions (Table 4).

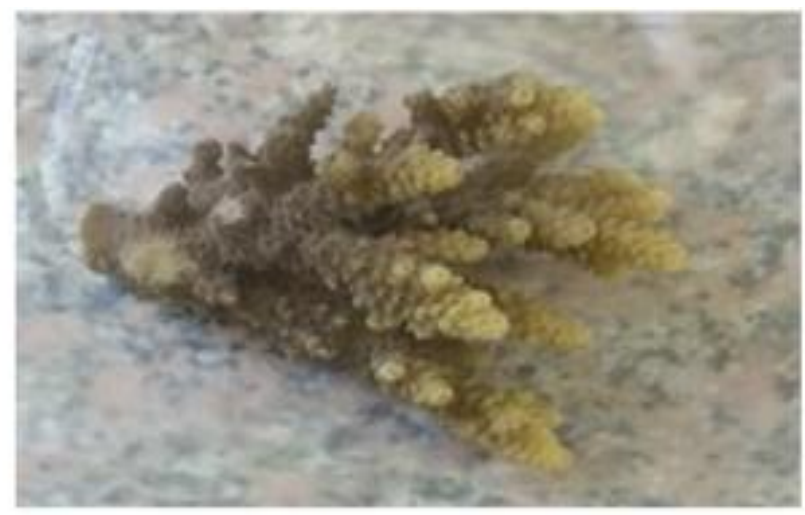

A. hemprichii

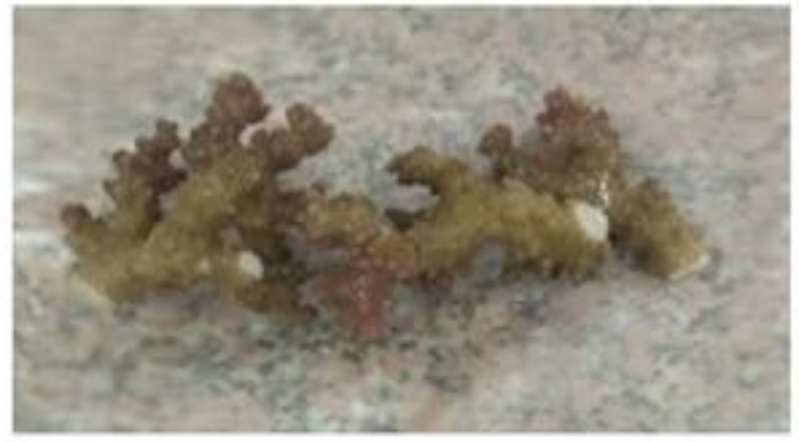

P. verrucosa

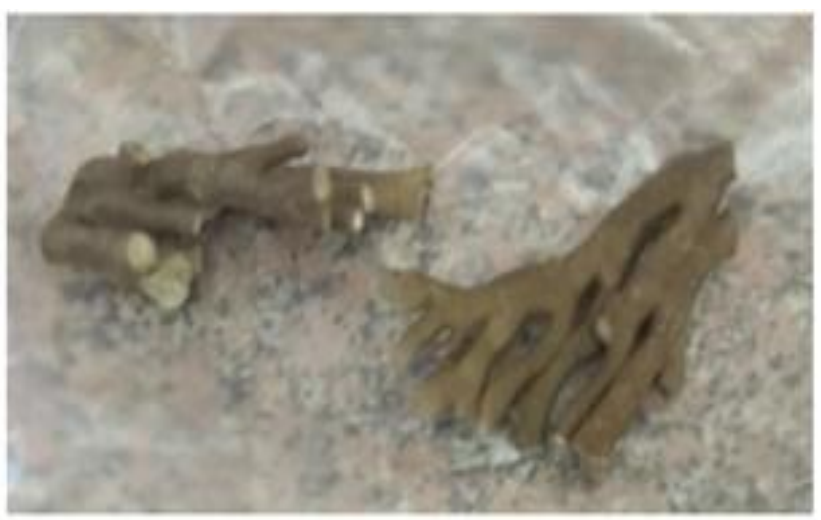

M. dichotoma

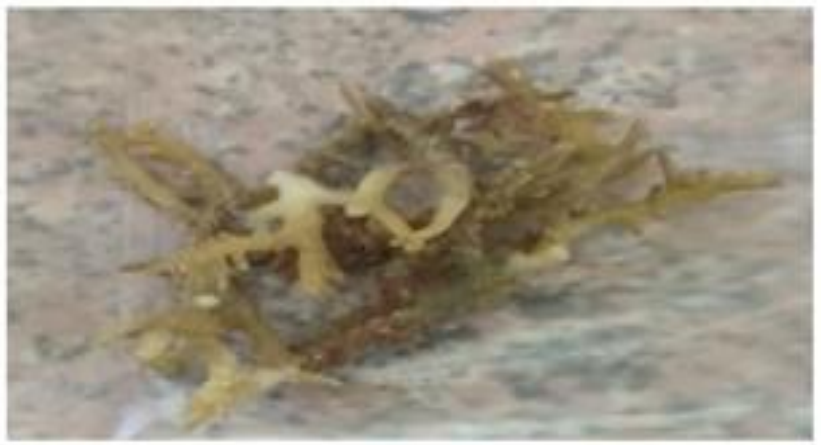

S. hystrix

Fig.2. Red Sea hard corals at the study area and used for preparing crudes extracts. 
Table 2. Antibacterial and antifungal activity of ethyl acetate extraction of hard corals species using well cut diffusion method

\section{Antibacterial and Antifungal activity ( $\mathrm{mm}$ ) of Coral species a concentration of $100 \mathrm{mg} \mathrm{ml}^{-1}$}

\begin{tabular}{ccccccc}
\cline { 2 - 6 } Pathogens & $\begin{array}{c}\text { Acropora } \\
\text { hemprichii }\end{array}$ & $\begin{array}{c}\text { Seriatopora } \\
\text { hystrix }\end{array}$ & $\begin{array}{c}\text { Milliopora } \\
\text { dichomata }\end{array}$ & $\begin{array}{c}\text { Acropora } \\
\text { austera }\end{array}$ & $\begin{array}{c}\text { Pocillopora } \\
\text { verrucosa }\end{array}$ & $\begin{array}{c}\text { Seriatopora } \\
\text { pistillata }\end{array}$ \\
\hline E. coli & 0.0 & 12.0 & 16.0 & 0.0 & $\mathbf{1 2 . 0}$ & 0.0 \\
\hline S. aureus & 18.0 & 16.0 & 18.0 & 12.0 & $\mathbf{2 0 . 0}$ & 20.0 \\
\hline E. faecalis & 16.0 & 16.0 & 0.0 & 12.0 & $\mathbf{1 6 . 0}$ & 0.0 \\
\hline B. subtillus & 0.0 & 0.0 & 0.0 & 0.0 & $\mathbf{0 . 0}$ & 0.0 \\
\hline P. aeruginosa & 0.0 & 12.0 & 0.0 & 0.0 & $\mathbf{1 6 . 0}$ & 0.0 \\
\hline A. flavus & 0.0 & 0.0 & 0.0 & 0.0 & $\mathbf{0 . 0}$ & 0.0 \\
\hline A. terreus & 0.0 & 14.0 & 14.0 & 0.0 & $\mathbf{1 6 . 0}$ & 0.0 \\
\hline F. solani & 0.0 & 0.0 & 16.0 & 16.0 & $\mathbf{2 2 . 0}$ & 10.0 \\
\hline
\end{tabular}

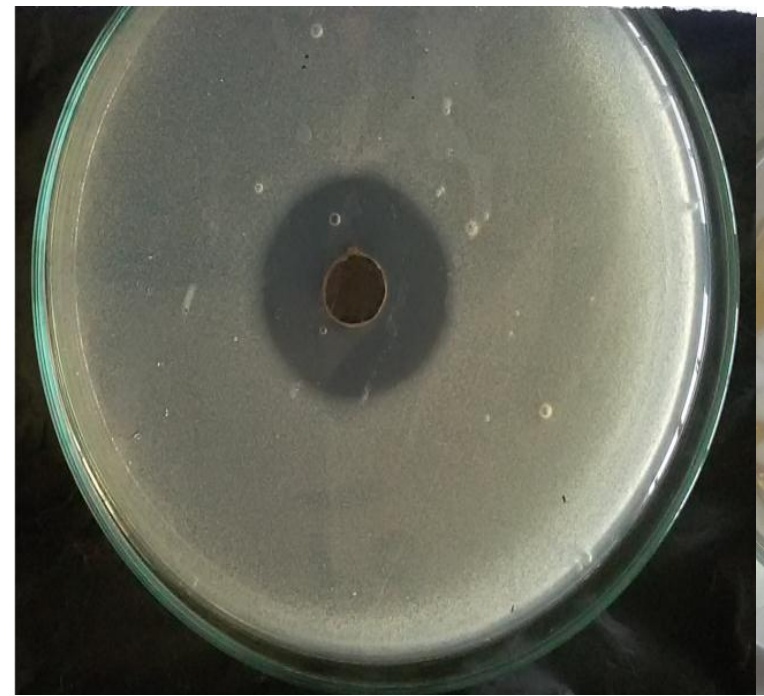

(A)

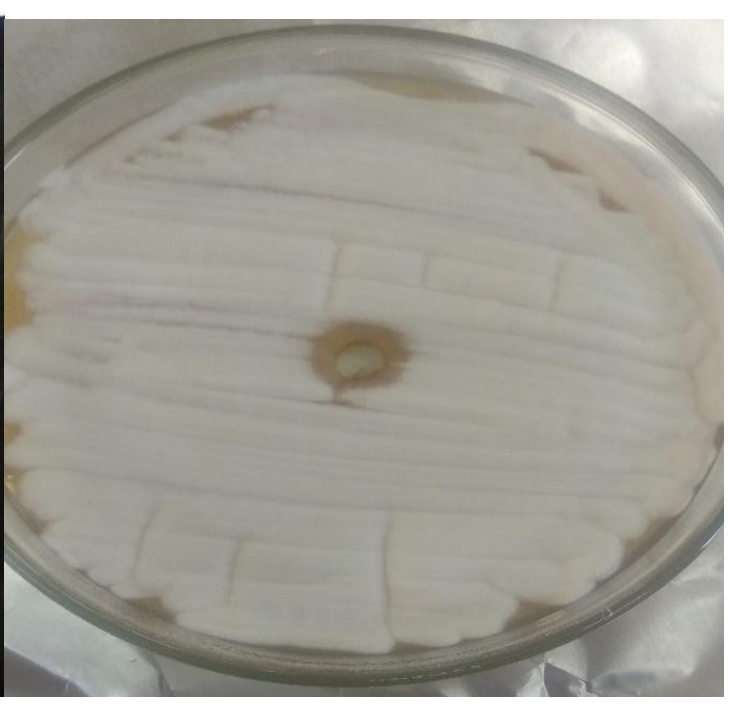

(B)

Fig.3. Antimicrobial and antifungal activity production from Pocillopora verrucosa crude extracts against (A) Staphylococcus aureus ATCC6538 and (B) Aspergillus terreus 
Table3: Minimum inhibitory concentration of crud extracts from Pocillopora verrucosa against bacterial and antifungal pathogens

\begin{tabular}{cc}
\hline Pathogens & MIC of P.verrucosa $(\mathbf{g} / \mathbf{m l})$ \\
\hline E. coli & $50 \pm 1$ \\
S. aureus & $12.5 \pm 1$ \\
E. faecalis & $25 \pm 1$ \\
P. aeruginosa & $25 \pm 1$ \\
A. terreus & $25 \pm 1$ \\
F. solani & $12.5 \pm 1$ \\
\hline
\end{tabular}

Table 4: Friedman's test of inhibition zone differences among coral species for different extractions.

\begin{tabular}{cc}
\hline & Ethyl acetate \\
\hline $\mathbf{Q}$ (observed value) & 11.08 \\
\hline $\mathbf{Q}$ (Critical value) & 11.07 \\
\hline $\mathbf{D F}$ & 5.00 \\
\hline p-value (Two-tailed) & 0.0498 \\
\hline alpha & 0.05 \\
\hline
\end{tabular}

\section{GC-MS chromatogram analysis}

The ethyl acetate extract of $P$. verrucosa was exposed to GC-MS analysis to identify its components (Fig. 4). These compounds were recognized through mass spectrum attached with GC. The active principles with their retention time [RT], molecular formula (MF), Molecular weight (MW) and concentration (\%) are accessible in Table 5. Table 2 shows the presence of bioactive compounds in $P$. verrucosaand the major compounds were: Piperidine, 1-methyl-,1-butanamine, 2-methyl-n-(2-methylbutylidene),3-methylbutyl-(3methylbutylidene) amine, Dimethyl trisulfide, Ethanethioic acid, S-[2(dimethylamino)ethyl] ester, Cyclooctasiloxane, hexadecamethyl-, N-Phenethyl-2methylbutylidenimine, 1h-purin-6-amine,[(2-fluorophenyl)methyl], 1-Hexadecanol, hexadecanoic acid, Phthalic acid butyl dodecyl ester, 9-Octadecenoic acid, 9,12,15Octadecatrienoic acid, 2,3-dihydroxypropyl ester, (Z,Z,Z)-, 4,7,10,13,16,19Docosahexaenoic acid, methyl ester, (all-Z)-, 2-([(2-ethylhexyl)oxy]carbonyl)benzoic acid, Tetradecanoic acid, hexadecyl ester, cis-9-Hexadecenoic acid, heptyl ester, 9-Octadecenoic acid (Z)-, tetradecyl ester. 


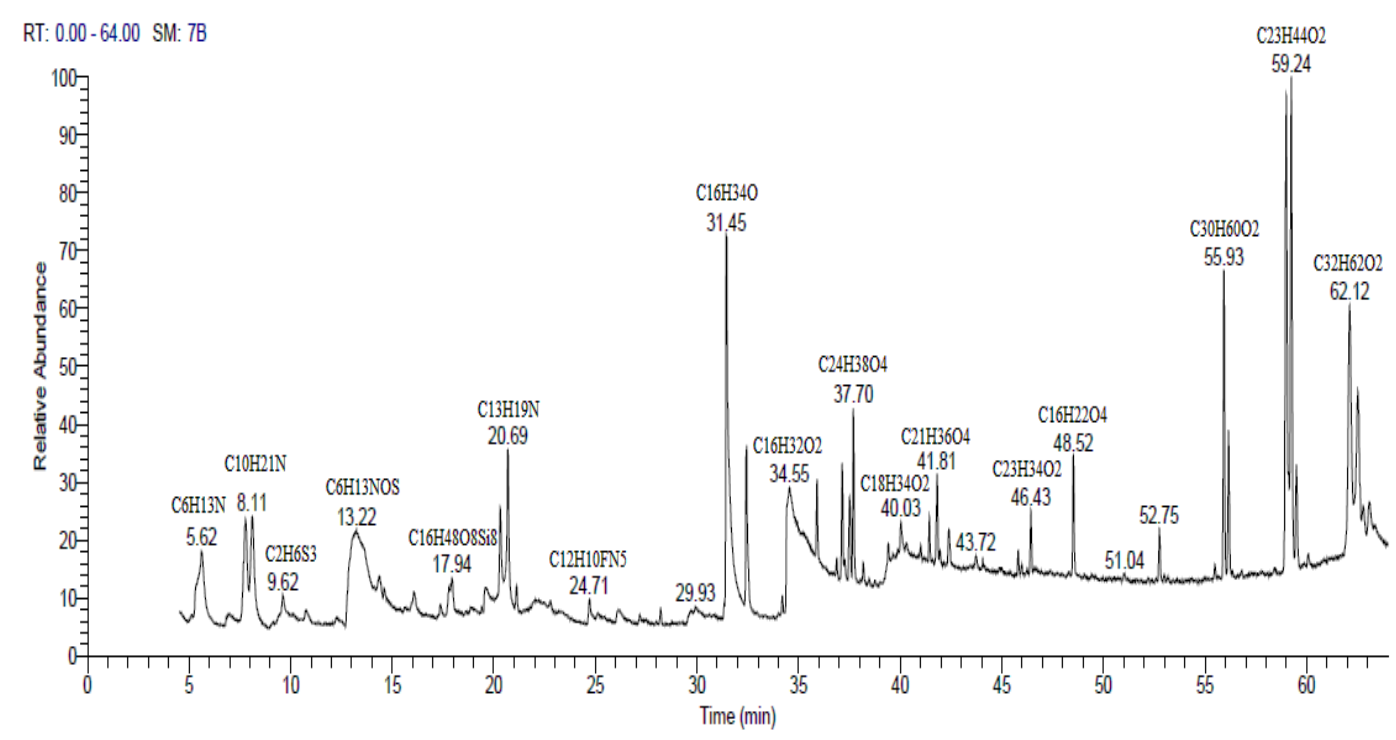

Fig.4: GC-MS chromatogram and structure formulas of compounds of the bioactive compounds extracted from Pocilloporaverrucosa.

Table 5: Components detected in Pocilloporaverrucosacrude extraction using ethyl acetate.

\begin{tabular}{|c|c|c|c|c|c|}
\hline No & $\begin{array}{l}\text { R T Value (In } \\
\text { Min.) }\end{array}$ & Compound & Mol. Formula & $\begin{array}{l}\text { Molecular } \\
\text { Weight }\end{array}$ & $\begin{array}{l}\text { Peak area } \\
\quad(\%)\end{array}$ \\
\hline 1 & 5.62 & Piperidine, 1-methyl- & C6H13N & 99 & 3.63 \\
\hline 2 & 7.78 & $\begin{array}{l}\text { 1-butanamine, } 2 \text {-methyl-n-(2- } \\
\text { methylbutylidene) }\end{array}$ & $\mathrm{C} 10 \mathrm{H} 21 \mathrm{~N}$ & 155 & 2.76 \\
\hline 3 & 8.12 & 3-methylbutyl-(3-methylbutylidene) amine & $\mathrm{C} 10 \mathrm{H} 21 \mathrm{~N}$ & 155 & 2.45 \\
\hline 4 & 9.62 & Dimethyl trisulfide & $\mathrm{C} 2 \mathrm{H} 6 \mathrm{~S} 3$ & 126 & 0.46 \\
\hline 5 & 13.03 & $\begin{array}{c}\text { Ethanethioic acid, S-[2 (dimethylamino)ethyl] } \\
\text { ester }\end{array}$ & C6H13NOS & 149 & 4.78 \\
\hline 6 & 17.94 & Cyclooctasiloxane, hexadecamethyl- & $\mathrm{C} 16 \mathrm{H} 48 \mathrm{O} 8 \mathrm{Si} 8$ & 592 & 0.94 \\
\hline 7 & 20.69 & N-Phenethyl-2-methylbutylidenimine & $\mathrm{C} 13 \mathrm{H} 19 \mathrm{~N}$ & 189 & 2.83 \\
\hline 8 & 24.17 & 1h-purin-6-amine,[(2-fluorophenyl)methyl] & C12H10FN5 & 243 & 0.68 \\
\hline 9 & 31.45 & 1-Hexadecanol & $\mathrm{C} 16 \mathrm{H} 34 \mathrm{O}$ & 242 & 8.16 \\
\hline 10 & 34.43 & Hexadecanoic acid & $\mathrm{C} 16 \mathrm{H} 32 \mathrm{O} 2$ & 256 & 4.94 \\
\hline 11 & 37.69 & Phthalic acid butyl dodecyl ester & $\mathrm{C} 24 \mathrm{H} 38 \mathrm{O} 4$ & 390 & 2.76 \\
\hline 12 & 40.3 & 9-Octadecenoic acid & $\mathrm{C} 18 \mathrm{H} 34 \mathrm{O} 2$ & 282 & 0.68 \\
\hline 13 & 41.81 & $\begin{array}{l}\text { 9,12,15-Octadecatrienoic acid, 2,3- } \\
\text { dihydroxypropyl ester, (Z,Z,Z)- }\end{array}$ & $\mathrm{C} 21 \mathrm{H} 36 \mathrm{O} 4$ & 352 & 1.72 \\
\hline 14 & 46.43 & $\begin{array}{c}\text { 4,7,10,13,16,19-Docosahexaenoic acid, } \\
\text { methyl ester, (all-Z)- }\end{array}$ & $\mathrm{C} 23 \mathrm{H} 34 \mathrm{O} 2$ & 342 & 1.05 \\
\hline 15 & 48.52 & $\begin{array}{c}\text { 2-([(2-ethylhexyl) oxy] carbonyl )benzoic } \\
\text { acid }\end{array}$ & $\mathrm{C} 16 \mathrm{H} 22 \mathrm{O} 4$ & 278 & 1.97 \\
\hline 16 & 55.93 & Tetradecanoic acid, hexadecyl ester & $\mathrm{C} 30 \mathrm{H} 60 \mathrm{O} 2$ & 452 & 5.25 \\
\hline 17 & 59.24 & cis-9-Hexadecenoic acid, heptyl ester & $\mathrm{C} 23 \mathrm{H} 44 \mathrm{O} 2$ & 352 & 8.83 \\
\hline 18 & 62.11 & 9-Octadecenoic acid (Z)-, tetradecyl ester & $\mathrm{C} 32 \mathrm{H} 62 \mathrm{O} 2$ & 478 & 6.44 \\
\hline
\end{tabular}




\section{DISCUSSION}

The aggregate objective of our study was to parallel the ability of extracts of Red Sea hard corals collected from the same habitat, to inhibit the growth of some pathogens. The biotechnological possibility of marine invertebrates such as corals has attracted the attention of researchers because of their ability to produce powerful bioactive compounds (Blunt et al. 2017). Marine corals are known to contain a rich variety of marine secondary metabolites and are considered a very diverse group of marine organisms. The bioactive compounds from marine corals have not only great significance in chemical ecology but also rapid various biological activities such as antitumor, antibacterial, antiviral and antifungal (Afifi et al. 2016). Our results have obviously shown in (Tables 2 and 4) and the result of antimicrobial activity in laboratory assays do not necessarily signalize a deficiency of antimicrobial chemical defense. Chemicals produced by higher organisms against cooccurring microorganisms may not simply kill or inhibit the growth of the target microorganism, but can act selectively against particular characteristics that are expressed by the bacteria. Both water and organic solvents were used to extract the bioactive compounds and all extracts give positive results. In similar study organic solvent was used to make extraction the hydrophilic and hydrophobic compounds from some hard corals species (Qaralleh et al. 2014; Mohammadizadeh et al. 2013). However, the extract using ethyl acetate of P.verrucosawas the most effective in the inhibition of most tested microorganisms. On antithesis that, the extracts of A. Hemprichii, A. austera and $S$. pistillata had the lowest effective one against all pathogens. Extracts from Scleractinia corals have been recorded to contain antimicrobial compounds (Geffen and Rosenberg 2005). The extracts of stony corals had no antimicrobial activity compared to extracts of soft corals that present good antimicrobial activity (Kelman et al. 2006). The coral Pocillopora damicornis prompt production antibacterial agents following a mechanical stress. Only antimicrobial compounds have also been notified in coralassociated bacteria (Geffen and Rosenberg 2005). Thus, antimicrobial activity is possible to engendered from both microbes and host sources (Mohamadizadeh et al. 2014). The alteration in the environment or the health conditions of the coral allows for changes to the microbial community. This also may suggest that production and extractions of bioactive compounds by mucus-associated bacteria is part of the scleractinian coral's defense strategy against pathogens (Ritchie 2006). In sundry studies the antibacterial activity of hard corals has been, resolved. Koh and his team reported, the alcohol extract of a great percentage of coral samples had antibacterial activity against a number of pathogenic bacteria (Koh 1997), while results acquired by (Kim 1994) explained antibacterial activity for both polar and non-polar (coral-derived) fractions with best activity associated with non-polar fractions. Antimicrobial activity was found particularly, among extracts obtained with non-polar rather than hydrophilic solvents (Gantar et al. 2011). Antibacterial activity in extracts of this hard species suggests a possible ecological function for their secondary metabolites. The antibacterial property of 
the hard corals extracts detect that they are potent enough to be less affected by bacterial organisms than the fungal (Mohamadizadeh et al. 2014). The ethyl acetate extract of P.verrucosa was subjected to Gas chromatography/mass spectrometry studies. Our data revealed that the main constituents of P.verrucosaethyl acetate crude extract were; organic acids, aldehydes, esters, carotene and their derivatives. These major compounds have all shown to have antimicrobial, antioxidant and cancer preventive in many reports (Al-Rubaye et al. 2017; Dhinakaran and Lipton 2014).Most of these compounds have been extracted from sea cucumber (Holothuriaatra) which collected from the Indian Ocean and the extraction had various compounds such as the flavonoids, phenolic components, terpenoids, saponins, alkaloids which were seen on their ability as antibacterial and anticancer activity (Dhinakaran and Lipton 2014). They are constituent of simple basic oils such as aromatic phenolic compounds, and diterpenoids, 1-Dodecene, Piperidine, Hexadecenoic acid, 9-Octadecenoic acid (Z)-, tetradecyl ester which has been notify to have numerous medicinal properties, they are used as antibacterial, antineoplastic, anti-carcinogenic, antimalarial, anti-ulcer and other pharmaceutical functions (Anadakumar et al. 2018; Thenmozhi and Rajan 2015; Vijisaral Elezabeth and Arumugam 2014; Tanod et al. 2018; Idan et al. 2015).

\section{CONCLUSION}

Some of the identified compounds in hard corals of Red Sea, Egypt, are rare compounds which are not yet announced in hard corals in the literatures. For future research, it is important to focus on finding the mechanisms used by corals to protect themselves against invasion, infection mechanisms and the type of chemical compound in coral extracts that inhibit bacterial and fungal growth. Therefore, extraction and purification that compounds can be useful for identification of their anti-microbial properties. On the other hand, although the amounts of identified compounds were not high to warrant economic value of studied hard corals, but identification of the bioactive compounds can be a good steering for showing chemical synthesis methods of identified compounds.

\section{REFERENCES}

Afifi, R.; Abdel-Nabi, I. M. and El-Shaikh, K. (2016). Antibacterial activity from soft corals of the Red Sea, Saudi Arabia. Journal of Taibah University for Science 10 (6):887-895.

Ibrahim, A.H.; Elabiary, H. D. and Hamed, M. M. (2020). Antimicrobial activity of some Egyptian marine invertebrates, Red Sea. Egyptian Journal of Aquatic Biology and Fisheries 24 (4):321-340.

Al-Rubaye, A. F.; Kaizal, A. F. and Hameed, I. H. (2017). Phytochemical screening of methanolic leaves extract of Malva sylvestris. Int. J. Pharmacognosy Phytochem. Res 9 (4):537-552. 
Anadakumar, A. S.; Jamuna, A.; Venkatachalapathi, and Paulsamy, S. (2018). Identification of bioactive compounds present in the crude methanolic leaf extract of Acalypha fruticosa Forssk. Through GC-MS analysis. Trends in Biosciences Journal 11 (7):1003-1013.

Berumen, M. L.; Hoey, A.; Bass, W. H. ; Bouwmeester, J.; Catania, D.; Cochran, J. ; Khalil, M. T. ; Miyake, S.; Mughal, M. and Spaet, J. L. (2013). The status of coral reef ecology research in the Red Sea. Coral Reefs 32 (3):737-748.

Blunt, J. W.; Copp, B. R.; Hu, W.-P. ; Munro, M. H.; Northcote, P. T. and Prinsep, M. R. (2009). Marine natural products. Natural product reports 26 (2):170-244.

Blunt, J. W.; Copp, B. R.; Keyzers, R. A.; Munro, M. H. andPrinsep, M. R. (2017). Marine natural products. Natural product reports 34 (3):235-294.

Cizeikiene, D.; Juodeikiene, G. ; Paskevicius, A. and Bartkiene, E. (2013). Antimicrobial activity of lactic acid bacteria against pathogenic and spoilage microorganism isolated from food and their control in wheat bread. Food Control $31(2): 539-545$.

Dar, M. (2005). Coastal habitats degradation due to chronic and recent landfilling along the Red Sea. Paper read at First Ain Shams University international conference on Environmental Engineering, April 9e11, Symp (pp. 773e786).

Debitus, C. (1998). The fascinating world of sponge chemistry and chemical ecology.

Dhinakaran, D. I. and Lipton, A. P. (2014). Bioactive compounds from Holothuria atra of Indian ocean. SpringerPlus 3 (1):673.

Gantar, M.; Kaczmarsky, L. T.; Stanić, D.; Miller, A. W. and Richardson, L. L. (2011). Antibacterial activity of marine and black band disease cyanobacteria against coral-associated bacteria. Marine drugs 9 (10):2089-2105.

Geffen, Y. and Rosenberg, E. (2005). Stress-induced rapid release of antibacterials by scleractinian corals. Marine Biology 146 (5):931-935.

Ibrahim, H. A.; Mohamed, S. Z. ; El-Regal, M. A. and Farhat, A. Z. (2012). Antibacterial activity of some Red Sea soft corals, Egypt. Blue Biotechnology Journal 1 (4):497.

Idan, S. A.; Al-Marzoqi, A. H. and Hameed, I. H. (2015.) Spectral analysis and antibacterial activity of methanolic fruit extract of Citrullus colocynthis using gas chromatography-mass spectrometry. African Journal of Biotechnology 14 (46):3131-3158.

Ismail, H. A.; Hanafy, M. H. Madkour, F. F. and Ahmed, M. I. (2017). Distribution of Soft Corals in the Egyptian Coasts of the Red Sea and Gulf of Aqaba. International Journal of Engineering Science 14944.

Kelman, D.; Kashman, Y. ; Rosenberg, E.; Kushmaro, A. and Loya, Y. (2006). Antimicrobial activity of Red Sea corals. Marine Biology 149 (2):357-363.

Kim, K. (1994). Antimicrobial activity in gorgonian corals (Coelenterata, Octocorallia). Coral Reefs 13 (2):75-80.

Kim, S.-K. (2012). -Marine Microbial Pharmacognosy: Aspects and Prospects. In Marine Pharmacognosy: CRC Press, 298-319.

Koh, E. G. (1997). Do scleractinian corals engage in chemical warfare against microbes? Journal of Chemical Ecology 23 (2):379-398. 
Madkour, M.; El-Metwally, M. and Hamed, A. (2006). Comparative study on different models for estimation of direct normal irradiance (DNI) over Egypt atmosphere. Renewable Energy 31 (3):361-382.

Mohamadizadeh, F.; Afkhami, M.; Ehsanpour, M. and Bahri, A. H. (2014). Screening for antibacterial, antifungal and cytotoxic agents in three hard coral species from Persian Gulf. Bangladesh Journal of Pharmacology 9 (2):171-175.

Mohammadizadeh, F.; Ehsanpor, M.; Afkhami, M.; Mokhlesi, A.; Khazaali, A. and Montazeri, S. (2013). Antibacterial, antifungal and cytotoxic effects of a sea cucumber Holothuria leucospilota, from the north coast of the Persian Gulf. Journal of the Marine Biological Association of the United Kingdom 93 (5):14011405.

Pagès, J.; Berthelo, S. ; Brossier, M. and Gourret, D. (2014). Statistical penalty analysis. Food Quality and Preference 32:16-23.

Qaralleh, H.; Idid, S. Z. Saad, S.; Susanti, D.; ALthunibat, O. and Sheikh, H. I. (2014). Antimicrobial activity of three hard coral species from South China Sea (Malaysia). SYLWAN 158 (4):20-25.

Ritchie, K. B. (2006). Regulation of microbial populations by coral surface mucus and mucus-associated bacteria. Marine Ecology Progress Series 322:1-14.

Rivera-Ortega, J., and Thomé, P. E. (2018). Contrasting antibacterial capabilities of the surface mucus layer from three symbiotic cnidarians. Frontiers in Marine Science $5: 392$.

Sabdaningsih, A.; Cristianawati, O.; Sibero, M. T.; Nuryadi, H.; Radjasa, O. K. Sabdono, A. and Trianto, A. (2017). Screening antibacterial agent from crude extract of marine-derived fungi associated with soft corals against MDRStaphylococcus haemolyticus. Paper read at IOP Conference Series: Earth and Environmental Science.

Stehli, F. G., and Wells, J. W. (1971). Diversity and age patterns in hermatypic corals. Systematic Zoology 20 (2):115-126.

Suresh, S.; Karthikeyan, S. ; Saravanan, P.; Jayamoorthy, K. and Dhanalekshmi, K. (2016). Comparison of antibacterial and antifungal activity of 5-amino-2mercapto benzimidazole and functionalized $\mathrm{Ag} 3 \mathrm{O} 4$ nanoparticles. Karbala International Journal of Modern Science 2 (2):129-137.

Tanod, W. A.; Aristawati, A. T. and Muliadin, M. (2018). Soft Coral (Sinularia sp.) Extracts with Antibacterial Activity. Omni-Akuatika 14 (1).

Thenmozhi, S., and Rajan, S. (2015). GC-MS analysis of bioactive compounds in Psidium guajava leaves. Journal of pharmacognosy and phytochemistry 3 (5):162166.

Velmurugan, S.; Viji, V. T.; Babu, M. M.; Punitha, M. J. and Citarasu, T. (2012). Antimicrobial effect of Calotropis procera active principles against aquatic microbial pathogens isolated from shrimp and fishes. Asian Pacific Journal of Tropical Biomedicine 2 (2):S812-S817.

Veron, J. E. N. (2000). Corals of the World.

Vijisaral Elezabeth, D. and Arumugam, S. (2014). GC-MS analysis of bioactive constituents of Indigofera suffruticosa leaves. J Chem Pharm Res 6 (8):294-300. 